\title{
De Vlaamse Hanze van Londen op het einde van de Xllle eeuw
}

Het kan een waagstuk schijnen nog iets nieuw over de Vlaamse Hanze van Londen pogen mede te delen na de vele artikels die er, tot in de jongste jaren toe, door de meest eminente historici aan gewijd werden (1). Onze bedoeling is het ook geenszins het probleem te hernemen; alleen een enigszins gekende, doch niet nader bestudeerde bron te ontleden en te bespreken in het kader van de reeds bereikte resultaten.

Alle studies over de hanze steunen bijna uitsluitend op haar blijkbaar gelijktijdige, maar niet gedagtekende Latijnse en Franse zogenoemde ", statuten ", welke laatst nog op definitieve wijze opnieuw werden uitgegeven en grondig gecommentarieerd (2). Van de lijsten van nieuwe leden van de hanze, die voorkomen in de Brugse stadsrekeningen van 1282-1299, werd bijna geen gebruik gemaakt. $\mathrm{Zij}$ hebben vrijwel alleen gediend om genoemde statuten bij benadering te dateren (3). Daarbij werd echter een vergissing begaan tengevolge van de onvolledigheid van de uitgave van die lijsten door L. Gilliodts-Van Severen (4). Hij publiceerde inderdaad

(1) We citeren hier alleen : $\mathrm{H}$. Pirenne, La hanse flamande de Londres (Bull. Acad. roy. Belg., cl. lettres, 1899, blz. 65-108) herdrukt in Les villes et les institutions urbaines, Parijs-Brussel, 1939, II, blz. 157-184; K. Höhlbaum, Ueber die flandrische Hanse von London (Hansische Geschichtsblätter, 1898, blz. 147-180); H. Van Werveke, "Hansa" in Vlaanderen en aangrenzende gebieden (Hand. van het Genootschap "Société d'Emulation" te Brugge, XC, 1953, blz. 5-42) en Das Wesen der flandrischen Hansen (Hansische Geschichtsblätter, 76, 1958, blz. 7-20).

(2) H. Van Werveke, Les ", statuts" latins et les, statuts" français de la Hanse flamande de Londres (Bull. Comm. roy. d'Hist., CXVIII, 1953, blz. 289-320).

(3) Zie K. Höhlbaum, op. cit., blz. 172 en vlg. en H. Van

Werveke, Les "Statuts", blz. 309-310.
(4) In Inventaire des archives de la Ville de Bruges, IV, blz. 270 278. 
slechts de lijsten voor de jaren 1285-1299. Zo komt het dat Höhlbaum en, na hem, Van Werveke meenden dat er geen lijsten staan in de rekeningen van 1282 en 1284 en de opname er van in de rekening van 1285 , m.a.w. het storten van de entreegelden van nieuwe hanzeleden in de stadskas, een nieuwigheid was. Als terminus ad quem voor de statuten werd dan 1285 voorgesteld, omdat die vermeende innovatie een reeds verder stadium veronderstelde, in de voortschrijdende hegemonie van Brugge in de schoot der hanze, dan datgene waarvan de Franse (d.i. de Brugse) versie van de statuten getuigt.

In feite was die nieuwigheid dus vóór 1282 ingetreden (5). Meer nog, de bewering van de schepenen van Brugge, in art. 10 van de Franse tekst, als hadden zij vroeger reeds van rechtswege de beschikking over de entreegelden van diegenen die te Brugge tot de hanze toetraden, blijkt aldus wel te betekenen dat bewuste bijdragen toen reeds in de stadskas gestort werden.

Er is bijgevolg, op grond van die lijsten, geen terminus ad quem vast te stellen. De twee statuten dagtekenen zeker van na 1241; zij kunnen evenwel nog jonger zijn dan het derde kwart van de XIIIde eeuw, tenzij het paleografisch criterium alle twijfel mocht uitsluiten.

Pirenne beschouwde die lijsten als ledenlijsten van het koopliedengild van Brugge, dat de naam van Londense Hanze zou aangenomen hebben, nadat deze laatste helemaal in verval geraakt was. Hij noemde die lijsten een herinnering (un souvenir) aan het bestaan van de hanze (6).

(5) De rekening van het jaar 1281/82 is de oudste die bewaard bleef, maar tevens de eerste die ter goedkeuring aan de vertegenwoordigers van de graaf voorgelegd werd.

(6) H. Pirenne, op cit., blz. 180-181. - Voor Ieper en Aardenburg verwijst hij op blz. 180, n. 3, naar teksten die aldaar dezelfde evolutie moeten aantonen. Voor Aardenburg gaat het ongetwijfeld om een anachronistische pretentie van de nakomelingen der vroegere patriciërs. De tekst dagtekent van 1328 (zie G.A. Vorsterman van Oyen, Rechtsbronnen der stad Aardenburg ('s- 
Indien de statuten, wegens het feit dat zij opgesteld werden ter gelegenheid van een betwisting in de schoot der hanze tussen de clan van Brugge en die van Ieper (7), meer dan een theoretische betekenis hebben en zelfs een evolutie in de hanze laten zien, dan zijn de ledenlijsten van louter practische aard (8).

Weliswaar belichten zij hoofdzakelijk de positie van Brugge in de hanze op het einde der XIIIde eeuw, doch daar Brugge van in het begin veruit het voornaamste lid was en haar zienswijze aan de andere leden poogde op te dringen, werpen zij enig licht op de evolutie van de hanze zelf in die periode en zelfs geruime tijd daarvoor.

De reeks Brugse stadsrekeningen van 1282-1301 (9) vertoont leemten en enkele rekeningen zijn bovendien onvolledig. Een lijst van nieuwe leden komt voor in elf rekeningen (10). In totaal telt men 199 nieuwe leden,

Gravenhage, 1892), blz. 44, § 43). Er kan moeilijk beweerd worden dat de Londense Hanze toen nog bestond. Of hier feitelijk het koopliedengild bedoeld werd is niet zeker. Een vermelding van dit laatste treft men aan in een document van het einde van 1311 (zie C. Wyffels, De oudste rekening der stad Aardenburg (13091310) en de opstand van 1311 (Archief uitgegeven door het Zeeuwsch Genootschap der Wetenschappen, 1949-1950, blz. 10-52), blz. 50. - De teksten voor Ieper wijzen niet in het minst op een dergelijke evolutie van het koopliedengild aldaar.

(7) Zie H. Van Werveke, Les "statuts", blz. 297 en vlg.

(8) Voor zover mij bekend vormen zij, samen met de ledenlijsten van de hanze van Sint-Omaars (St.-Omaars, Stadsbibliotheek, hschr. 889), de enige dusdanige bronnen in verband met hanzen in onze gewesten. Wij hebben een aanvang gemaakt met een gelijkaardige studie van laatstgenoemde lijsten.

(9) Bewaard in het stadsarchief te Brugge. - In die rekeningen vindt men ook enkele posten waarin de , hanze" der XVII steden vermeld wordt. Een paar zijn het citeren waard, omdat zij een kleine aanvulling vormen op het weinige wat men weet nopens de organisatie van die hanze. Rek. 1284/85, $\mathrm{f}^{\circ} 9$ : Item, tunc (22 aug. 1285) nuntio a majore 17 villarum misso: 4 s.; rek. 1283/84, $\mathrm{f}^{\circ} 15 \mathrm{v}^{\circ}$ : Tunc (3 sept. 1284), nuncio afferenti litteras de 17 villarum: $10 \mathrm{~s}$. Aan het hoofd van de hanze stond aldus een meier en er was zeker ook een klerk.

(10) Die lijsten zijn, zoals gezegd, onvolledig uitgegeven door L. Gilliodts : zie hoger. We hebben het onnodig geoordeeld ze hier 
hetzij gemiddeld 18 per jaar.

Hoewel het ons niet mogelijk was alle namen te identificeren, we hebben tijdens onze opzoekingen toch de stellige overtuiging opgedaan dat het uitsluitend om Brugse burgers gaat. Men mag bijgevolg aannemen dat poorters van andere bij de hanze aangesloten steden - ook van diegene die politiek en economisch nauw met Brugge verbonden waren - verder hun lidmaatschap in Engeland, "gewonnen" hebben.

Van de 199 nieuw ingeschrevenen betaalden 72 een toegangsrecht van 5 s. st. en 119 een van 30 s. st., naar gelang hun vader al of niet lid was van de hanze. De 3 d. st. die volgens de statuten door ieder nieuw lid nog dienden aan genoemde bedragen toegevoegd te worden, ten bate van de hanzefunctionarissen, zijn hier niet vermeld. Men mag veronderstellen dat die penningen hun statutaire bestemming gekregen hebben, alhoewel we geen enkele concrete aanduiding in die zin aangetroffen hebben.

Er dient nog aangestipt dat de bijdragen aanvankelijk geboekt werden in ponden sterl.; van 1294 af echter in ponden par. Daar de waardeverhouding tussen beide pondenstelsels $3 / 10$ was (11), beliepen de bijdragen respectievelijk 16 s. 8 d. par. en 5 lb. par.

Zeven personen betaalden evenwel een veel aanzienlijker bedrag, namelijk :

volledig te publiceren, daar de integrale uitgave van de Brugse stadsrekeningen voor de besproken periode binnen afzienbare tijd zal geschieden.

(11) De verhouding bleef dezelfde tussen $1283 / 84$ en 1302 : zie stadsrekeningen $1283 / 84$ en $1287 / 88$, rubriek Receptum de hansis en J. Colens, 1302. Le compte communal de la ville de Bruges (Brugge 1886), blz. 12. 
Zwalewe Willem (1290)

Rompot Willem (1290)

Zevekote Niklaas v. (1292)

Formator Simon (1294) "

Hegher Pieter (1295)

"

"

Grise Pieter (1298)

"

"

Pinkere Jan (1298), pro arreragio hanse sue
6 lb. 10 s. st. (12)

6 lb. 10 s. st. (12)

6 lb. 12 s. st. (13)

5 lb.

par.

16 s. 8 d. par.

16 lb. 13 s. 4 d. par.

$5 \mathrm{lb}$.

par.

16 s. 8 d. par.

16 lb. 13 s. 4 d. par.

$5 \mathrm{lb}$.

par.

16 s. 8 d. par.

Formator en Pinkere betaalden in totaal blijkbaar evenveel als Hegher en Grise. Die vier nieuwe leden stortten aldus de bijdragen van 5 s. st. en 30 s. st., alsmede een bijdrage van $5 \mathrm{lb}$. st., in totaal dus $6 \mathrm{lb}$. $15 \mathrm{~s}$. st. Daarop steunend mag men aannemen dat de bijdragen van Zwalewe en Rompot bestonden uit $5 \mathrm{lb}$. st. plus 30 s. st. Het entreegeld van Zevekote bedroeg 2 s. st. meer. Wat dit geringe verschil te betekenen heeft konden we niet uitmaken. Het betreft vermoedelijk een vergissing.

De bewuste zeven nieuwe leden waren ongetwijfeld handwerkers die eerst lid van het koopliedengild dienden te worden, tegen betaling van 1 mark goud of 10 mark zilver, en na sedert een jaar hun handwerk verzaakt te hebben. De $5 \mathrm{lb}$. st. vertegenwoordigden inderdaad de waarde van 10 mark zilver (14). Zwalewe en Rompot (en Zevekote) betaalden daarenboven het gewone entreegeld van 30 s. st. Dit alles in overeenstem-

(12) Die bedragen zijn geschreven boven razuur. Er stond blijkbaar eerst XVI lb. XIII s. IIII d.

(13) Ook hier werd eerst een ander bedrag geschrapt en nadien overschreven.

(14) Zie J. Buntinx, Het memoriaal van Jehan Makiel (Kon. Com. Gesch., in-8, Brussel 1944), blz. XL. 
ming met de statuten. Van 1294 af betaalden de vroegere handwerkers ook nog de bijdrage van 5 s. st. Dit blijkt een weinig logische nieuwigheid te zijn.

Van drie dier zeven nieuwe leden konden we het beroep achterhalen (15). Zevekote en Zwalewe waren, na hun intrede in de hanze, respectievelijk lakensnijder en drapier; Hegher werd onder de wevers én de poorters geciteerd in 1280, dus vóór zijn opname in de hanze. We mogen aldus aannemen dat zij vroeger het beroep van wever uitgeoefend hadden.

Tenslotte wordt Willem Cocus de jonge (1290) gratis tot de hanze toegelaten. Er is daarbij uitdrukkelijk gestipuleerd : concessa hansa sua per scabinos.

Uit dit alles volgt dat, zoals de Brugse schepenen het in art. 10 van de Franse statuten beweerden, de entreegelden in de stadskas gestort en als stadsinkomsten be'schouwd werden (16). Meer nog, ook het hoge toegangsrecht tot het koopliedengild, betaald door handwerkers, kwam eveneens in de stadskas terecht.

Minstens tot 1290, vermoedelijk tot 1292 , werden de toelatingsvoorwaarden, zoals ze beschreven staan in de statuten, letterlijk toegepast. Van 1294 af betaalden de handwerkers ook nog de bijdrage van $5 \mathrm{~s}$. st. De $3 \mathrm{~d}$. st. waarvan sprake in de statuten kwamen niet in de stadskas en gingen waarschijnlijk naar de hanzefunctionarissen.

Dit lijkt ons van aard om te besluiten dat we niet met het tot hanze herdoopt koopliedengild van Brugge, maar nog immer met de Vlaamse Hanze van Londen te doen hebben.

Verder zijn het de schepenen en niet de leden van de hanze, zoals men het zou mogen verwachten, die beslissen nopens gratis opname in de vereniging.

(15) Zie bijlage.

(16) In 1291/92 werd een lening van $36 \mathrm{lb} .13 \mathrm{~s} .4 \mathrm{~d}$. toegestaan aan Meikin, de stadsklerk, op de entreegelden van de nieuwe leden : zie rekening ad annum, $\mathrm{f}^{\circ} 23 \mathrm{bis}$. 
Van de door de Brugse schepenen in art. 9, 10 en 11 van de Franse statuten voorgestelde hervormingen (17) blijkt tenslotte ook niets terecht gekomen.

Opvallend is het relatief groot aantal nieuwe leden (minstens 23 op 199) die van buiten Brugge, uit Vlaanderen of den vreemde, komen. Zij betaalden natuurlijk allen 30 s. st. Tien onder hen vonden we terug in de lijsten van de nieuwe poorters, die eveneens in de stadsrekeningen voorkomen. Voor de overigen staat de plaats van herkomst naast hun naam vermeld in de lijsten zelf van de nieuwe hanzeleden, ofwel wijst hun familienaam op de plaats van herkomst. Zij waren hoogst waarschijnlijk ook onlangs poorter geworden. Men krijgt hier eveneens sterk de indruk dat alleen Brugse burgers lid van de hanze werden te Brugge (18).

We laten hieronder de lijst van die personen volgen met aanduiding van de plaats van herkomst en de datum waarop zij lid van de hanze (H.) en eventueel burger (B.) werden.

Badeloghe

Bernaie, Willem de

Caloets, Jacob fs Jacob
Groede (bij Oostburg)

H. : 9.2 .1290

Bayonne $\quad$ B. : 21.7 .1284

H. : 22.7.1284

B. : 2.4.1282

(17) In het kort samengevat : een ieder - dus niet alleen Bruggelingen - zou zijn hanze te Brugge kunnen „winnen " (art. 9). Alle te Brugge betaalde entreegelden zouden in een kist met drie sloten bewaard worden, ten behoeve van de hanze (art. 10). Van de in Engeland betaalde entreegelden zou aldaar de helft of een derde verteerd worden; de rest zou in genoemde kist gestort worden (art. 11).

(18) Naast veel namen in de lijst van 1298/99 wordt genoteerd: tamquam liber opidanus, licet stat in dubio, hetgeen ook in die richting wijst.

(19) Caloets was ongetwijfeld een Lombard. Hij was hoogst waarschijnlijk verwant aan Jacob van Caloets die poorter werd op 22.1.1285 en aangeduid wordt als Lombard : stadsrekening 1284/85, $f^{\circ} 4 v^{\circ}$. 
Cantin, Jan

Chalons, Jan van, fs Jan

Damme, Antoon van, fs Antoon

Dentoingnam, Pieter

Duese, Arnold van

Hille, Willem van den

Hont, Hendrik

Inghelzone, Jan

Ketel, Nikolaas

Leie, Lamsin van der

Lischeboon, Vincent

Matheus van

Lombaerd, Antcon

Luke, Bertrand de

Sancto Johanne de Piet de Porch, Remout de
Abbeville

B. en H. : 15.10 .1298

Chalons (21)

B. en H. : 23.12.1291

Damme (21)

B. en H. : 10.6.1298

Montpellier H. : 26.8.1284

Cahors (Cauwers)

B. en H. : 22.7.1284

Zedelgem

H. : 1.9 .1285

Pittem

H. : 4.12 .1281

Oudenaarde H. : 6.2.1291

Lissewege H. : 9.4.1291

? $\quad$ B. en H. : 3.8 .1298

Lissabon (21) B. : 1.4.1284 H. : 24.12.1283-13.6.1284 Asti (Aist) H. : 11.2.1282

B. : 19.9 .1282

Bayonne H. : 8.7.1284

Saint-Jean-Pied-de-

Port (21) H. : 25.9 .1282

(20) Het Wiic was in de XIIIde eeuw de voornaamste aanlegplaats der stad Brugge, doch maakte geen deel uit van het rechtsgebied van de Brugse schepenbank, maar lag op de heerlijkheid van Praet (zie J. Marechal, Bijdrage tot de geschiedenis van het bankwezen te Brugge (Brugge 1951), blz. 13-14.

(21) We menen dat de familienamen hier op de plaats van herkomst wijzen. - Voor Vincent Matheus van Lischeboon steunen we echter niet alleen op de familienaam, maar ook op zijn dubbele voornaam die eerder wijst op zuiderse oorsprong. Dubbele voornamen komen hier inderdaad in de XIIIde eeuw niet voor. Toch dient ook gewezen te worden op het feit dat er in de XIIIde eeuw een koopmansgeslacht Liscobonus te Diksmuide leefde, dat relaties had met Genua en Londen. Zie de vermelding van een Wilielmus en een Nicolinus Liscobonus in 1253 bij R. Doehaerd, Les relations commerciales entre Gênes, la Belgique et l'Outremont (Inst. Hist. Belge de Rome, Etudes d'Hist. écon. et soc., vol. II, Brussel-Rome, 1941), I, blz. 156, en II, blz. 436. Het is niet volkomen uitgesloten dat onze Lischeboon tot dit geslacht zou kunnen behoren. 
Een Spanjaard (22)

Spanje

H. : 24.11.1287

Sus, Geraard de

Piacenza

B. : 21.7 .1284

H. : 27.7.1288

Tsocard, Niklaas

Diksmuide

H. : 4.2 .1291

Vos, Simon

Oudenaarde H. : 25.4.1285

Wale, Jan gezeid

Boerneville (23)

H. : 24.11.1287

Zot, Gillis

Leke

H. : 4.1.1292

Dertien zijn afkomstig van Italië, Frankrijk, Spanje of Portugal; de overigen komen uit Vlaamse lokaliteiten. Bernaie, Cantin, Chalons, Duese, Van Damme en Van der Leie werden tegelijker tijd burger en hanzelid. Zeer waarschijnlijk was zulks ook het geval met Caloets en Lischeboen.

De vreemdelingen, met uitzondering van Caloets, die een woekeraar was en de Sus, een hostelier (24), mag men beschouwen als te Brugge gevestigde kooplieden. Hun verblijf aldaar schijnt nochtans over het algemeen niet definitief geweest te zijn. Behalve Caloets, de Sus en Jan Wale vindt men geen van hen terug in 1292 en 1297.

Onder de nieuwe leden telt men 21 vrouwen (ruim $10 \%$ ), waarvan vier dochters waren van hanzeleden. Zulks wijst wellicht op de frequente economische activiteit van de vrouw in het middeleeuwse Brugge.

Het meest interesseert de afkomst, het beroep en de sociale stand (d.i. het bezit) van de nieuwe leden. Niettegenstaande uitgebreide opzoekingen (25) hebben we,

(22) Het was Pieter Calkre die uit zijn naam entreegeld betaalde.

(23) Boernevile waarschijnlijk te identificeren met Bournonville, Fr., Pas-de-Calais, arr. Boulogne, kant. Desvres.

(24) Zie bijlage.

(25) Hoofdzakelijk werden volgende bronnen geraadpleegd. Een lijst van Brugse borgen in verband met de ". Moerlemaie" in 1280/81 : Rijksarchief Gent, Oorkonden der Graven van Vlaanderen, Chronologisch Supplement, $\mathbf{n}^{\circ}$ 113. (Die lijst zal binnenkort uitgegeven worden als bijlage van een artikel over de Moerlemaie). 
betreffende die punten, slechts nopens 100 leden (de helft dus) inlichtingen kunnen inwinnen (26). We hebben ze verwerkt in een tabel die in bijlage afgedrukt is.

Van bedoelde 100 personen zijn er 43 wier beroep gekend is. $\mathrm{Zij}$ zijn als volgt te verdelen over de genoteerde beroepen :

drapiers, lakensnijders en wolhandelaars (27): 16 (of

18) waarvan zeven (of acht) 5.s. st., zes (of vijf)

$30 \mathrm{~s}$, drie $6 \mathrm{lb} .10 \mathrm{~s}$. st. betaalden en een gratis opgenomen werd;

wijntappers en wijnhandelaars (27): 7 (of 6) waarvan twee 5 s. en vijf (of vier) $30 \mathrm{~s}$. betaalden;

kousscheppers (28) : 3 die allen $30 \mathrm{~s}$. betaalden;

- De stadsrekening van 1302 uitgegeven door J. Colens, zie hoger. - De lijst van poorterlijke ruiters van 1292 uitgegeven door J. De Smet, De inrichtirig van de Poorterlijke Ruiterij te Brugge in 1292 en haar Indeling in gezindheden in 1302 (Versl. en Med. Kon. Vl. Akad. Taal- en Lett., 1930, blz. 487-505). - Een lijst van terugbetaling van belastingen uit het jaar 1298 : stadsarch. Brugge, rek. 1298, $f^{\circ} 23 \mathrm{v}^{\circ}-29 \mathrm{r}^{\circ}$. (Zie over die lijst en het tarief van de belasting C. Wyffels, De oorsprong der ambachten in Vlaanderer' en Brabant (Verh. Kon. Vl. Acad. Wet., Lett, en Schone Kunst. v. België, dl. 13, 1951), blz. 67-68, n. 51). L. Gilliodts-Van Severen, Inventaire des Archives de la Ville de Bruges, (Bruges, 1871-1885), 9 dln. - L. Verriest, Les registres de la "Loi" de Tournai de 1302 et Liste des otages de Bruges (1301) et de Courtrai (Bull. Comm. roy. Hist., t. LXXX, 1911, blz. 369-527).

(26) Het feit dat niettegenstaande de rijke gelijktijdige Brugse documentatie nopens de helft van de nieuwe leden geen inlichtingen betreffende bedoelde punten konden ingewonnen worden, wijst er reeds op dat het grotendeels moet gaan om ambachtslieden en poorters met gering vermogen.

(27) In de bronnen is niet immer het onderscheid tussen die beroepen te maken.

(28) Volgens art. 7 van de Franse tekst van de statuten verliest een hanzelid dat kleermaker wordt zijn hanze. Kousscheppers stonden schijnbaar een trapje hoger dan kleermakers.

(29) De schoenmakers worden in beide statuten bestempeld als ", ovremarkes", hetgeen betekent dat zij hun beroep moesten laten varen en eerst één mark goud aan het koopliedengild betalen vooraleer tot de hanze toegelaten te worden. Er valt op te merken dat Wouter van der Mote en Laurens Prumbout als schoenmakers vermeld worden in 1281 en eerst lid worden van de hanze resp. in 1298 en 1292. Van der Mote betaalde 5 s. st. entreegeld, het- 
hosteliers : 3 (of 2) waarvan 2 (of 1) 5 s. betaalden en een $30 \mathrm{~s}$;

schoenmakers (29): 2 waarvan een 5 s. en een 30 s. betaalde;

klerken : 2 waarvan een 5 s. en een 30 s. stortte;

kruidenier (30) : 1 (30 s.) verver : 1 (30 s.)

paternostermaker: 1 (30 s.) lamminwerker : 1 (30 s.)

brouwer : 1 (30 s.)

bakker : 1 (30 s.)

woekeraar : 1 (30 s.)

begijn : 1 (30 s.) makelaar (31) : 1 (30 s.)

Wat het fortuin van 69 nieuwe leden, in 1292 en 1297, betreft onderscheidt men volgende categorieën, rekening er mede gehouden dat we telkens het hoogste cijfer in aanmerking genomen hebben.

39 leden bezaten minder dan $1.000 \mathrm{lb}$., waaronder 1 met 200 lb., 2 met 240 lb., 19 met 400 lb., 3 met $600 \mathrm{lb}$. en 14 met $800 \mathrm{lb}$;

20 leden bezaten 1000 à $2000 \mathrm{lb}$;

1 lid bezat 2000 à $3000 \mathrm{lb}$;

9 leden bezaten meer dan $3000 \mathrm{lb}$.

Tenslotte konden we het beroep achterhalen van de vader van een elftal leden. Zes waren drapiers (waarvan drie ook lid van de hanze), drie hosteliers (waarvan een lid van de hanze), een wijntapper en een blander (32).

$$
* * *
$$

geen er op wijst dat zijn vader ook hanzelid geworden was. Prumbout betaalde 30 s. st. $\mathrm{Nu}$ is het evenwel mogelijk dat hij reeds $5 \mathrm{lb}$. st. betaald had of nog: zou betalen op een ander tijdstip. Jan Pinkere betaalde ook die som als achterstal : zie hoger blz. 9.

(30) Kruideniers werden blijkbaar niet gelijkgesteld met diegenen $k i$ poisent par livres: zie art. 7 van de Franse tekst van de statuten.

(31) Leden die makelaar werden verloren hun hanze volgens art. 7 van de Franse tekst. Willem Ram werd lid van de hanze in 1283; als makelaar wordt hij vermeld in 1302. Is hij intussen uit de hanze getreden?

(32) Chrysolotus van Veurne en zijn zoons Gillis en Niklaas werden lid op dezelfde datum (22.8.1298). Jan Gabriel werd lid op 7.6.1291 en zijn zoon Niklaas op 14.5.1295.

(33) G. Espinas-H. Pirenne, Recueil de documents pour servir 
Aan hetgene voorafgaat menen we enkele beschouwingen te mogen vastknopen, die wellicht wat meer licht werpen op de evolutie van de Vlaamse Hanze van Londen.

De Brugse schepenen hadden zich reeds, vóór het ontstaan van het conflict met Ieper, dat aanleiding gaf tot het opstellen door beide partijen van de "statuten" van de vereniging, met de organisatie er van ingelaten, namelijk wat het verwerven van het lidmaatschap der Bruggelingen betrof en de bestemming van de entreegelden. Die noviteiten alsmede hun streven om aan de organisatie, altijd onder Brugse leiding, een vastere vorm te geven hadden ongetwijfeld aanleiding gegeven tot het conflict. Vandaar ook de reeks innovaties die zij in hun versie van de statuten poogden te doen erkennen door de andere steden. Deze blijken niet op de Brugse voorstellen ingegaan te zijn. Intussen werd de "etatisatie" van de hanze te Brugge volledig : zij kwam geheel onder contrôle van de magistraat.

Inmenging van de schepenbank ziet men overigens ook te Ieper (en in de andere steden). Volgens art. 2 van de Latijnse statuten konden de schepenen en raadslieden het toegangsrecht van de handwerkers tot het stedelijk koopliedengild verhogen. De Ieperse schepenen vaardigden keuren uit met betrekking tot de hanze : iemand die geen lid was van de hanze en naar Engeland toog of er zijn koopwaren heen stuurde liep de hoogste stedelijke boete van $50 \mathrm{lb}$. op (33); een hanzelid dat koopwaren van een buitenstaander naar Engeland voerde of zich associeerde met een buitenstaander liep dezelfde boete op en verloor daarenboven zijn lidmaatschap (34); een burger die de stad ontvluchtte omwille

à l'histoire de l'industrie drapière en Flandre (Comm. roy. d'Hist., in- $4^{\circ}$, Brussel 1906-1924), dl. III, blz. 501, $\$ 1$ (z.d., XIIIde eeuw).

(34) Ibidem, $\$ 2$ (z.d., XIIIde eeuw).

(35) J. De Smet, Les keures intédites du plus ancien livre de keures d'Ypres (Bul. Comm. roy. d'Hist, XCIV, 1930, blz. 389-481), 
van de hanze, verloor zijn poorterschap voorgoed (35). En wanneer, in 1289, de wolhandel met Engeland voor ieder burger open verklaard werd, waren het weer de schepenen die als voorwaarde de toetreding tot de Londense Hanze stelden (36).

Het is zelfs hoogst waarschijnlijk dat, aangezien de rijke kooplieden de schepenbanken grotendeels bezetten, de stadsmagistraten van het begin af zich met de vereniging ingelaten hebben. Wellicht mag men zelfs verder gaan en de oprichting van de hanze eerder terugvoeren op een initiatief van de stadsmagistraten van Brugge, Ieper en andere Vlaamse steden, die daarbij de gewoonten welke golden in een of andere stedelijke hanze (bvb. die van Brugge of Ieper) in de nieuwe organisatie overnamen.

$\mathrm{Er}$ is met reden beweerd geworden dat de meest essentiële trek van de Vlaamse Hanze te zoeken is in haar exclusivisme ten overstaan van de handwerkers, inzonderheid die van de draperie (37). Ook mag men aannemen dat de hanze oorspronkelijk alleen groothandelaars op Engeland groepeerde. Onze lijsten nu laten zien dat, zo het exclusivisme ten overstaan van de wevers en andere minder gewaardeerde handwerkers tot het einde toe bleef bestaan (38), de hanze op het einde der XIIIde eeuw, te Brugge althans, in het geheel niet meer een beperkte groepering van rijke kooplieden was. $\mathrm{Na}$ 1280 immers zijn we getuige van een echte invasie in de

blz. $479, \S 1$ (z.d., XIIIde eeuw).

(36) G. Espinas-H. Pirenne, op. cit. III, blz. 501, § 13.

(37) Zie H. Pirenne, op. cit., blz. 173-174 en H. Van Werveke, Das Wesen, blz. 16.

(38) De totale bijdrage (voor hanze én gild) die zij op het einde der XIIIde eeuw dienden te betalen, hetzij $22 \mathrm{lb} .10 \mathrm{~s}$. par., was wel een zeer hoog, doch niet prohibitief voor burgers - handwerkers met een bezit van $400 \mathrm{lb}$. of $800 \mathrm{lb}$. zoals Rompot, Zevekote en Hegher. (Zie bijlage).

(39) Warnkoenig-Gheldolf, Histoire de la Flandre, IV, blz. 230. 
hanze van ambachtslieden en poorters met gering vermogen. De hanze is er in zeer sterke mate gedemocratiseerd. De overgrote meerderheid van de leden schijnen drapiers, lakensnijders, wolhandelaars, wijnhandelaars, en wijntappers van gering formaat te zijn. Er waren echter ook ambachtslieden zoals bakkers, kruideniers, meerseniers en kousscheppers die bezwaarlijk iets met handel op Engeland uitstaans hadden. Voor hen betekende lid worden van de hanze ongetwijfeld alleen opgenomen worden in de "poorterie", hetgeen blijkbaar, naast het bewustzijn tot de hogere stand te behoren, ook zekere bevoorrechtingen meebracht. In de eerste plaats (theoretisch althans) verkiesbaar te zijn tot schepen, krachtens de stadskeure van 1241 (39). Verder benoemd te kunnen worden tot zekere stadsambten, zoals deken en vinder. Voor de draperie weten we bepaald dat deze ambtenaren lid dienden te zijn van de hanze (40).

Wanneer werd de democratisering van de hanze ingezet? Zulks is moeilijk te bepalen, doch men mag aannemen dat dit, te Brugge ten minste, lang vóór 1280 gebeurd is. Vermoedelijk is het begonnen in de draperie. Naarmate het monopolie van de Vlaamse groothandel op Engeland, sedert het eerste kwart der XIIIde eeuw, door de stijgende activiteit van de vreemde kooplui bedreigd werd, kregen de wevers gelegenheid zich omhoog te werken tot drapiers (4i1). Na de draperie volgden dan andere bedrijfstakken. De democratisering van de hanze lijkt ons gelijke tred te houden met het verval van de actieve Vlaamse handel op Engeland.

De opname van nieuwe leden te Brugge zelf is waar-

(40) C. Wyffels, Oorsprong, blz. 65-66.

(41) H. Van Werveke in De koopman-ondernemer en de ondernemer in de Vlaamse lakennijverheid van de middeleeuwen (Med. Kon. Vl. Akad. voor Wet., Lett. en Schone Kunsten v. België, jg. VIII, $\left.\mathrm{n}^{\circ} 4,1946\right)$, blz. 23 en 25 , heeft aangetoond dat die evolutie te Dowaai reeds vóór 1248 en te Gent vóór 1275 ingezet was.

(42) H. Van Werveke, Das Wesen, blz. 15. 
schijnlijk ook te beschouwen als een overwinning van de homines novi : vermijden nog de reis naar Engeland te moeten doen. Van dat ogenblik af hebben de schepenen zich zeker hoe langer hoe actiever met de organisatie van de Brugse afdeling van de hanze in Vlaanderen ingelaten. Brugge volgde aldus haar eigen weg in de hanze, hetgeen zeker haar samenhang sterk moet bedreigd, zoniet virtueel verbroken hebben.

Het lijkt ons niet zeer gewaagd om de hypothese vooruit te zetten dat de Vlaamse hanze als interstedelijke groepering van kooplieden, waarschijnlijk tussen 1212 en 1241 (42), op initiatief van de patricische stadsmagistraten in het leven geroepen werd, juist om de steeds dreigender wordende opgang van handwerkers gemakkelijker te kunnen te keer gaan (43). Die samen-

(43) Men kan opwerpen dat de voorheen bestaande stedelijke hanzen, elk in hun stad, wel dit resultaat moesten kunnen o-reiken. Het lijkt ons nochtans aannemelijk dat, op zeker ogenblik, de economische en sociale toestand in een of meer steden (en daarbij denken we in de eerste plaats aan Brugge), zo geëvolueerd had dat de locale hanzen nog moeilijk het verschijnen van niet-leden op de Engelse marktplaatsen konden weren. Anderzijds moesten dergelijke steden ook een zekere aantrekkingskracht uitoefenen op opkomende elementen uit andere steden, waar de "hanzetucht" nog niet of veel minder verzwakt was. Om een en ander was het in het belang van al die steden om hun locale hanzen te versmelten in een eenvormige gemeenschappelijke hanze, waartoe het initiatief genomen werd door de stedelijke magistraten. Tenslotte traden kleinere en jongere steden, waar misschien geen locale hanzen bestonden, tot de interstedelijke hanze toe, wellicht niet zonder enige dwang vanwege de grote centra.

(44) G. Espinas-H. Pirenne, op. cit., III, blz. 501, \& 13. Het komt ons voor dat de opkomst van de drapiersstand te Brugge veel vroeger gebeurd is dan te Ieper. In 1281 (Rijksarchief Gent, oorkonden der Graven van Vlaanderen, Chron. Supplement, $\mathbf{n}^{\circ} 113$ ) worden tal van wevers tegelijker tijd als wever en als burgensis vermeld. - Van de 13 drapiers vermeld onderaan een project van 1281/82 (G. Espinas-H. Pirenne, op. cit., I, blz. 368) zijn er zeven die in 1292 tot de poorterlijke ruiterij behoren. Van een is het bezit hoger dan $3000 \mathrm{lb}$. : van de anderen ligt het tussen 1000 en $2000 \mathrm{lb}$. - In een lijst van Brugse wolhandelaars die klagen over het ongeld dat van hen geëist werd te Ieper, treft men tal van weinig of niet bekende namen aan. Het gaat ongetwijfeld om Brugse drapiers die te Ieper relatief kleine hoeveelheden wol gingen verkopen. Over Nikolaas Joedemare bezitten we uitzonderlijk meer inlichtingen 
bundeling van krachten heeft echter weinig gebaat: de welgesteld geworden ambachtslieden dwongen hoe langer hoe meer hun opname in de hanze af, zodat in de laatste decennia van de XIIIde eeuw, te Brugge althans, de hanze volledig haar oorspronkelijke betekenis verloren had en een standsgroepering van de "poorterie " gewor. den was. De glorietijd van de hanze schijnt aldus van relatief korte duur geweest te zijn.

Zoals gezegd hebben Ieper en de andere hanzesteden de Brugse voorstellen in de Franse tekst van de statuten niet aanvaard. $\mathrm{Zij}$ hebben voort geëist van hun burgers dat zij hun hanze wonnen in Engeland. Toelaten dat dit ook te Brugge mocht geschieden zou een ondermijning betekend hebben van de bevoorrechte positie van de groothandelaars. De opname van de drapiers (en an-

(Zie bijlage). Hij is in 1292 gerangschikt in de groep van de poorters met een bezit van 1000 à $2000 \mathrm{lb}$. Nu dagtekent die niet gedateerde lijst, die door de uitgevers van het Recueil tegen het einde van de XIIIde eeuw gesitueerd wordt, van vóór juli 1285 . Op die datum ontvangt de stad $3371 / 2 \mathrm{lb}$. van Adelise, het weeskind van Niklaas Walkier welke in onze lijst vermeld staat. Vermoedelijk dagtekent de lijst van na 1 april 1281, datum waarop aan vreemdelingen de verkoop van wol op de jaarmarkt en de gewone marktdagen toegestaan wordt, mits zij ongeld betalen zoals de Ieperlingen (G. Espinas-H. Pirenne, op. cit., blz. 682, § 5). Daar de klachten lopen over het ongeld dat gedurende twee jaar geëist werd van 1 september af, mag men aannemen dat de lijst slaat op verhandelingen van wol ten laatste na 1 september 1283. - Tenslotte notere men dat de toegang tot de Vlaamse hanze voor de lakensnijders reeds verplichtend was in 1284 (G. Espinas-H. Pirenne, op. cit., I, blz. 417, § 174).

Dit alles laat m.i. toe aan te nemen dat de drapiersstand, zoals hij uit die bronnen naar voren treedt, niet plots is ontstaan, maar het resultaat is van een langzame groei die verschillende decennia vóór 1280 geduurd heeft.

Tenslotte merke men op dat, toen de Ieperse drapiers alleen nog maar de toelating verleend werd om wol aan te kopen voor hun bedrijf , aan deze zijde van de zee" en de vreemde wolhandelaars op de Ieperse markt mochten verschijnen (G. Espinas-H. Pirenne, op. cit., III, blz. $82, \S 5$ ), de Brugse drapiers hun wol reeds buiten Brugge gingen verkopen, zoals blijkt uit de hoger besproken lijst.

Ook met die gegevens dient rekening gehouden te worden in verband met de verschillende houding van de Brugse en Ieperse schepenen ten overstaan van de hanze. 
dere welgestelde ambachtslieden ?) is te Ieper dan ook veel later en trager gebeurd dan te Brugge. Pas in 1289 schijnen de schepenen de hanze open te stellen voor de drapiers (44):

\section{WYFFELS}

\section{BIJLAGE}

Tabel van nieuwe leden van de Vlaamse hanze, te Brugge, tussen 1281 en 1299

Naast de naam van het nieuw lid treft men het jaartal aan van intrede in de hanze en het betaalde toegangsrecht, het beroep met het jaartal van de vermelding, het bezit volgens de lijst van de poorterlijke ruiters van 1292 en het bezit berekend naar een belasting geheven in 1297. - Voor de voornaamste gebruikte bronnen zie hoger blz. 13 noot 25 .

- We houden er aan hier onze erkentelijkheid te betuigen aan Professor dr. H. Van Wervek die onze bijdrage in handschrift heeft willen doorlezen en daarbij enkele verbeteringen heeft voorgesteld waarvan wij dankbaar hebben gebruik gemaakt. 
C. WYFFELS
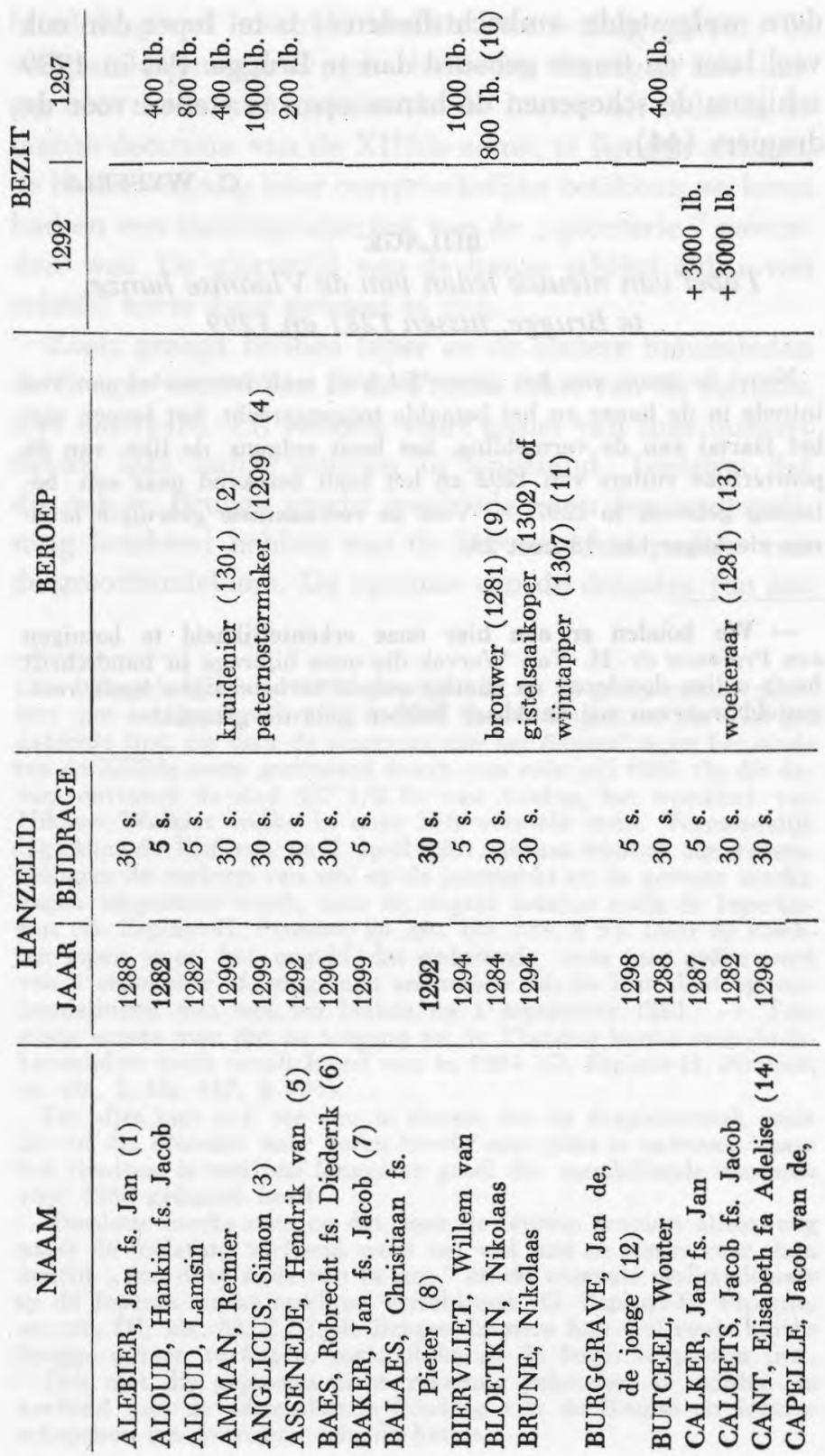


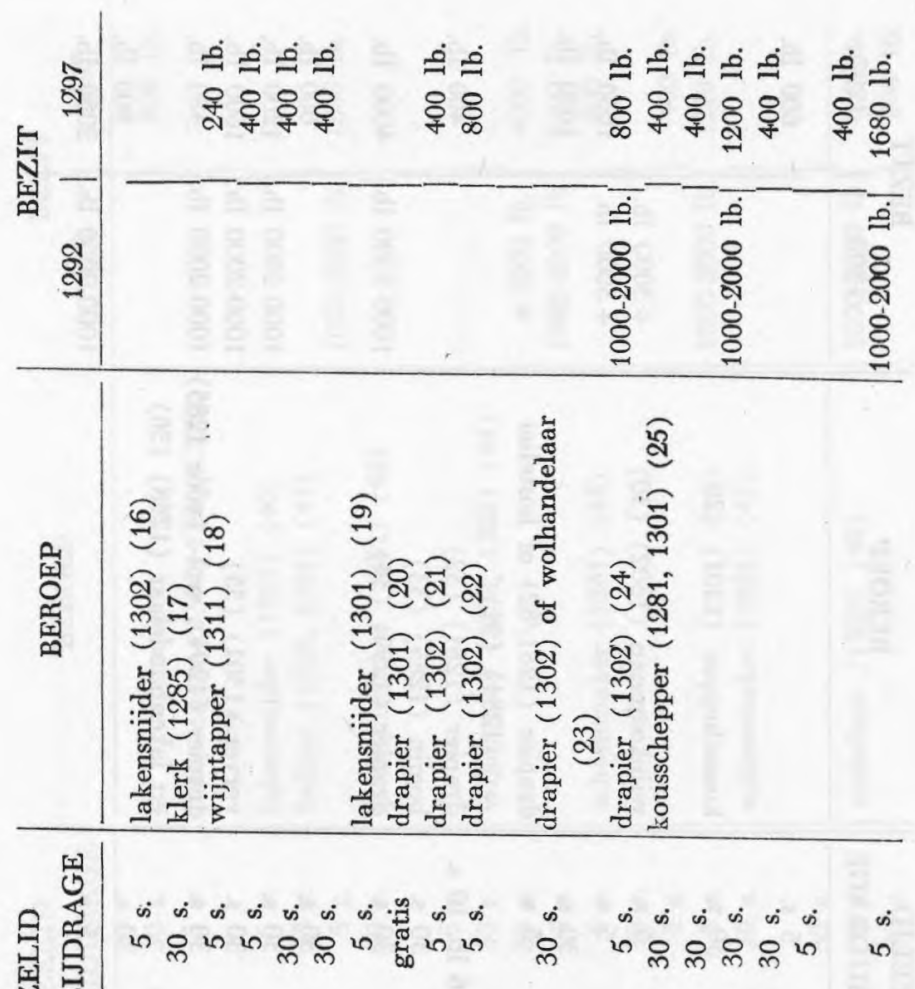


C. WYFFELS
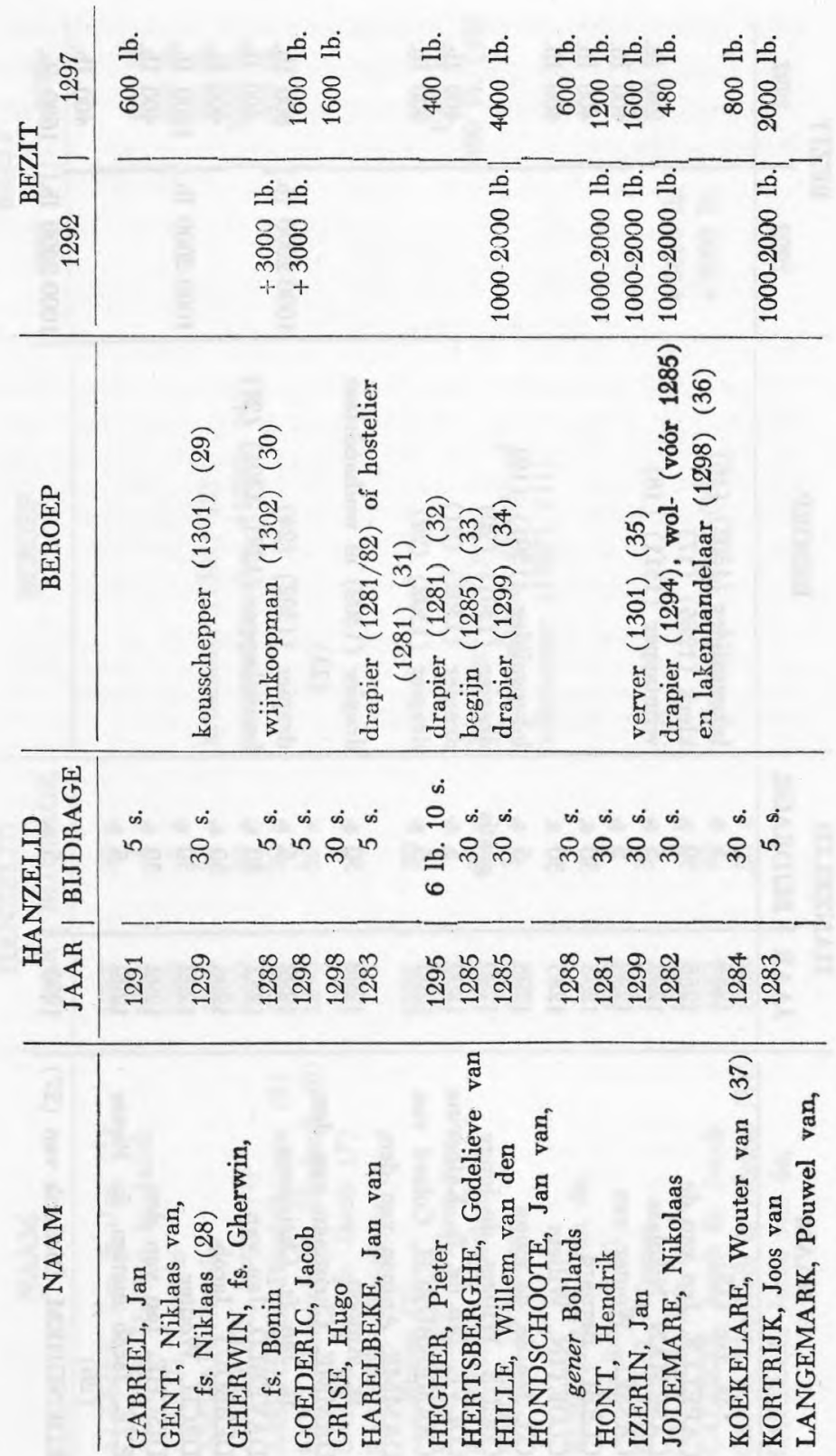


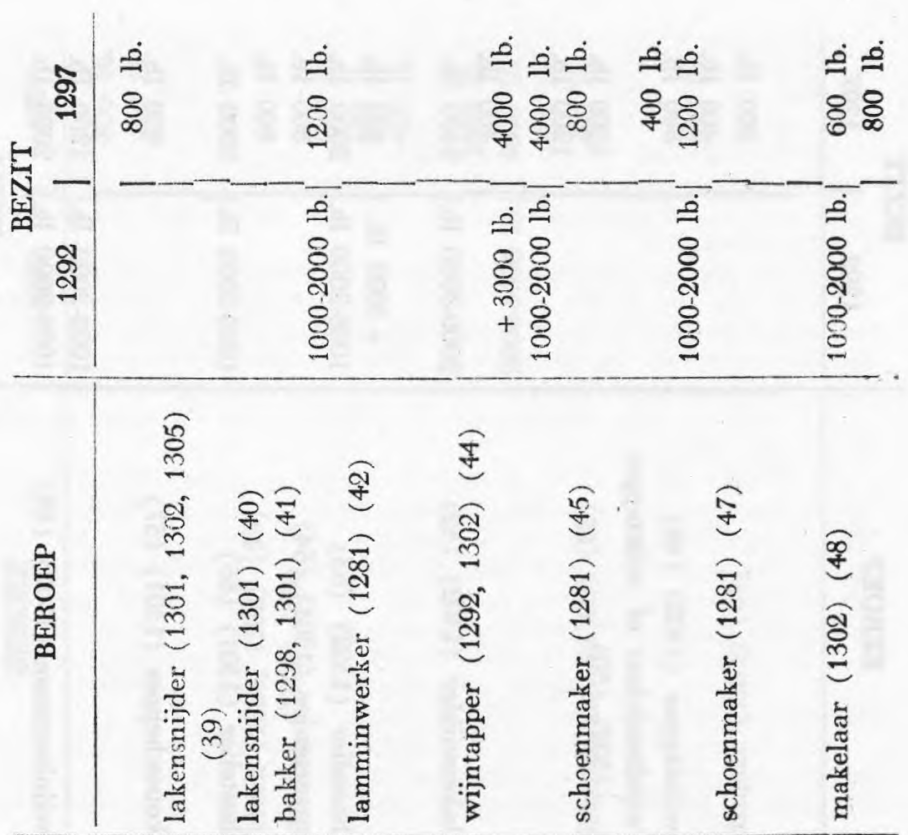

秀

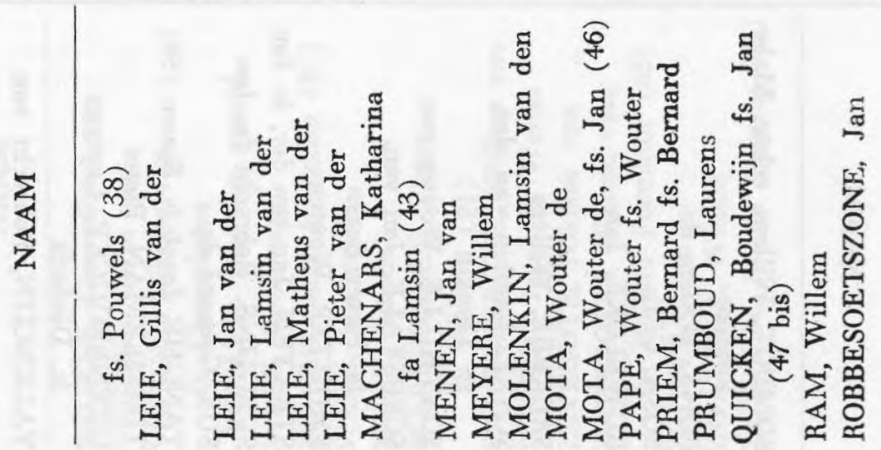



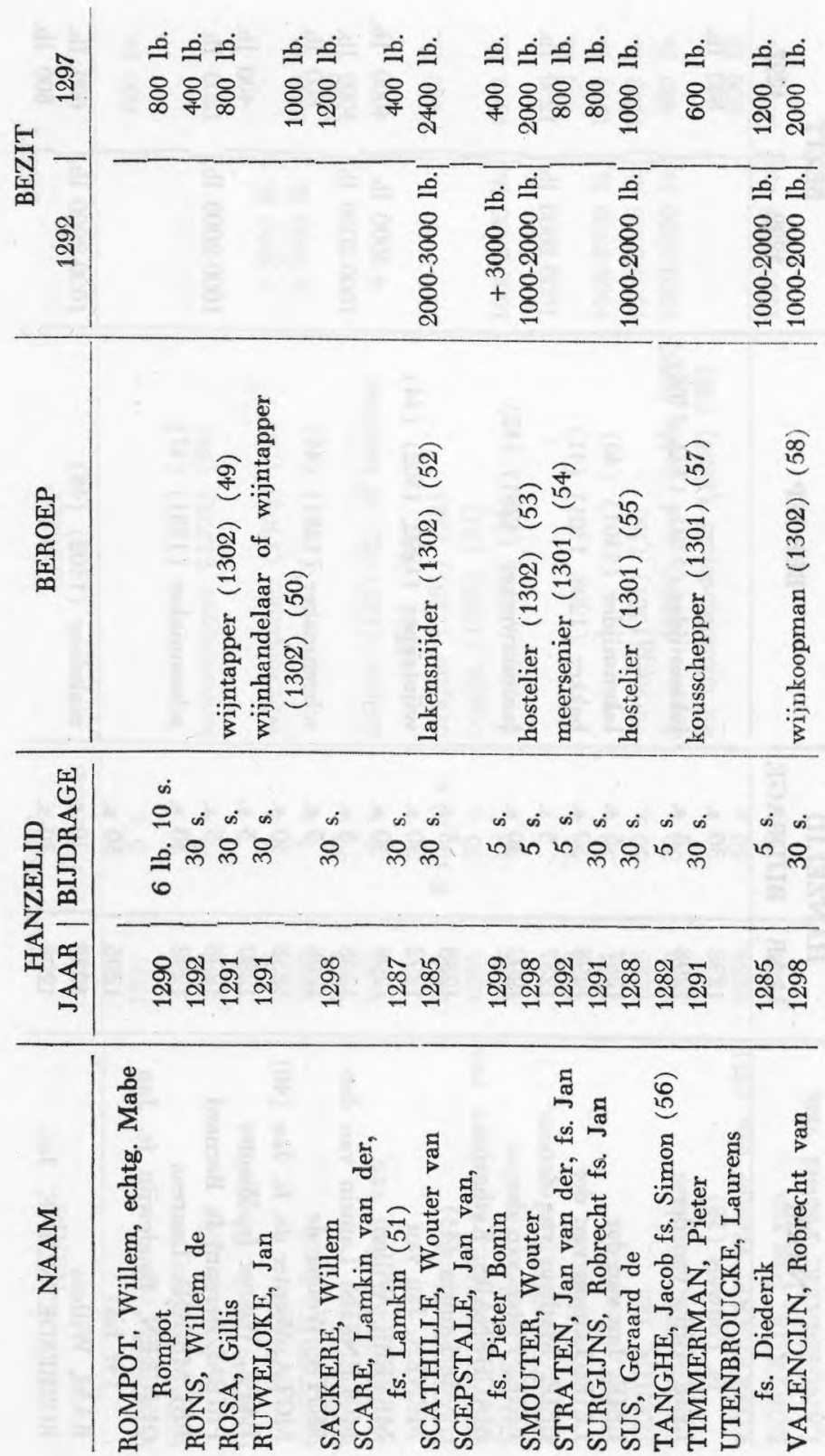


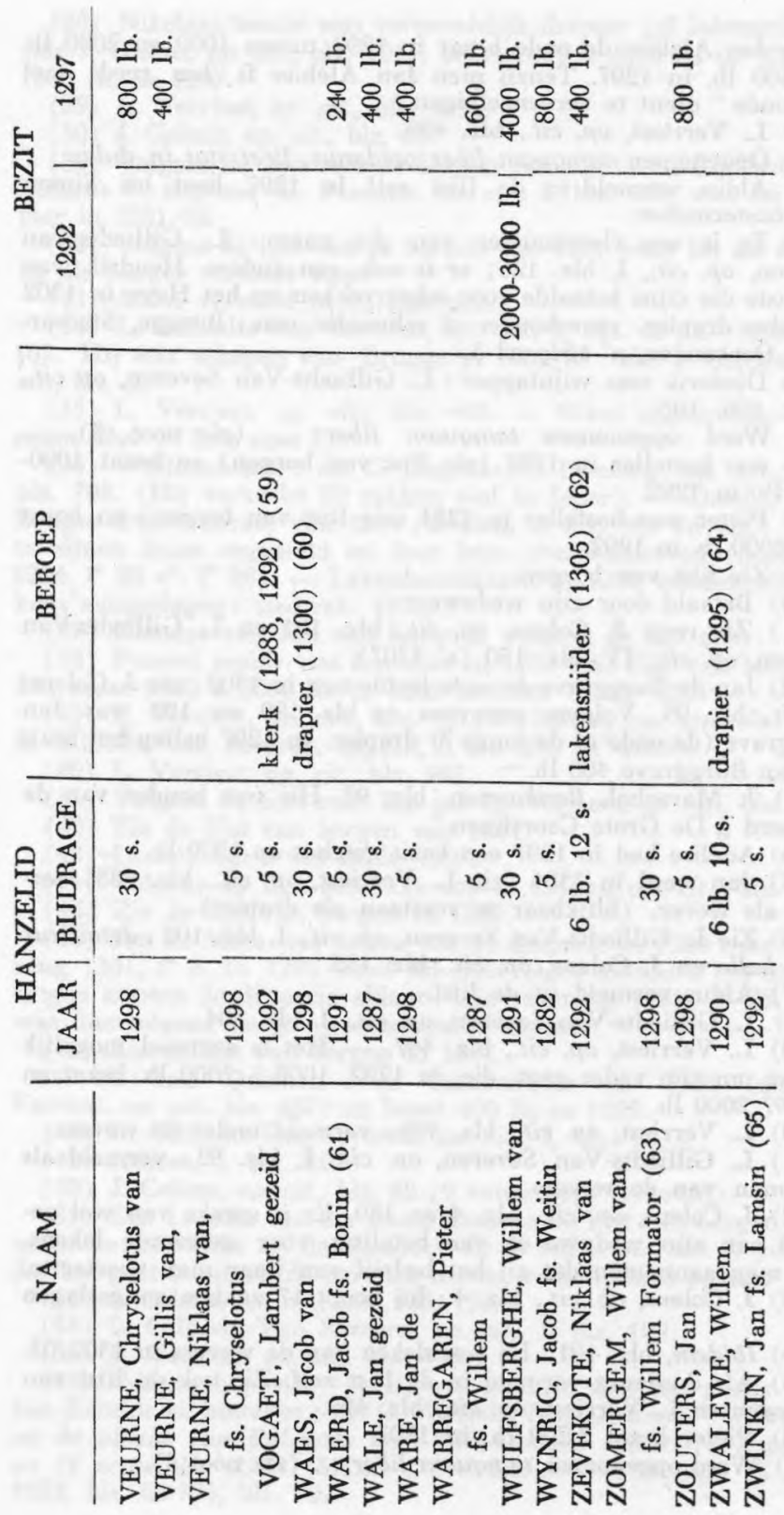


(1) Jan Alebier de oude bezat in 1292 tussen 1000 en $2000 \mathrm{lb}$. en $1600 \mathrm{lb}$. in 1297. Tenzij men Jan Alebier fs Jan reeds met , de oude" dient te vereenzelvigen.

(2) L. Verriest, op. cit., blz. 498.

(3) Opgenomen tamquam liber opidanus, licet stat in dubio.

(4) Aldus vermeld in de lijst zelf. In 1297 heet hij Simon Paternostermaker.

(5) $\mathrm{Er}$ is een vleeshouwer van die naam: L. Gilliodts-Van Severen, op. cit., I, blz. 126; er is ook een andere Hendrik van Assenede die cijns betaalde voor scheerrekken op het Hoye in 1302 en aldus drapier, raamhouder of scheerder was : Brugge, Stadsarchief, Oorkonden, $\mathrm{n}^{\circ} 154$, vel 3.

(6) Diederik was wijntapper : L. Gilliodts-Van Severen, op cit., I, blz. 106, 108.

(7) Werd opgenomen tamquam liber ... (zie noot 3). Jacob was hostelier in 1281 (zie lijst van borgen) en bezat 1000 $2000 \mathrm{lb}$. in 1292.

(8) Pieter was hostelier in 1281 (zie lijst van borgen) en bezat 1000-2000 lb. in 1292.

(9) Zie lijst van borgen.

(10) Betaald door zijn weduwe.

(11) Zie resp. J. Colens, op. cit., blz. 101 en L. Gilliodts-Van Severen, op. cit., IV, blz. $150\left(\mathrm{a}^{\circ} 1307\right)$.

(12) Jan de Burggrave de oude leefde nog in 1302 : zie J. Colens, op. cit., blz. 95. Volgens gegevens op blz. 189 en 190 was Jan Burggrave (de oude of de jonge ?) drapier. In 1297 beliep het bezit van Jan Burggrave $400 \mathrm{lb}$.

(13) J. Marechal, Bankwezen, blz. 93. Hij was houder van de lommerd "De Grote Caorsijnen".

(14) Adelise had in 1297 een bezit geschat op $1200 \mathrm{lb}$.

(15) Jan werd in 1301 (zie L. Verriest, op. cit., blz. 488) vermeld als wever, (blijkbaar te verstaan als drapier).

(16) Zie L. Gilliodts-Van Severen, op. cit., I, blz. 102 : detailleur en le halle en J. Colens, op. cit., blz. 135.

(17) Aldus vermeld in de lijst.

(18) L. Gilliodts-Van Severen, op. cit., I, blz. 304.

(19) L. Verriest, op. cit., blz. 497. - Het is evenwel mogelijk dat het om zijn vader gaat, die, in 1292,1000 à $2000 \mathrm{lb}$. bezat en in $12972000 \mathrm{lb}$.

(20) L. Verriest, op. cit., blz. 486 : vermeld onder de wevers.

(21) L. Gilliodts-Van Severen, op. cit., I, blz. 92 : vermeld als hoofdman van de wevers.

(22) J. Colens, op. cit., blz. 4 en 189. Er is sprake van wol geleverd aan zijn weduwe en van betaling voor geleverde lakens. Men mag aannemen dat zij het bedrijf van haar man voortzette. wol.

(23) J. Colens, op. cit., blz. 4 : hij koopt 17 zakken aangeslagen

(24) Ibidem, blz. 191 : hij was deken van de wevers in 1302/03.

(25) Als dusdanig vermeld in de lijst zelf. Zie ook de lijst van de borgen en L. Verriest, op. cit., blz. 495.

(26) Pieter bezat $3.200 \mathrm{lb}$. in 1297.

(27) Werd opgenomen tamquam liber... (zie noot 3 ). 
(28) Nikolaas senior was vermoedelijk drapier (of lakensnijder) (zie J. Colens, op. cit., blz. 191), bezat 1000 à $2000 \mathrm{lb}$. in 1292 en $1000 \mathrm{lb}$. in 1297.

(29) L. Verriest, op. cit., blz. 495.

(30) J. Colens, op. cit., blz. 83.

(31) Volgens de lijst van de borgen van 1281 was hij hostelier. Volgens G. Espinas -H. Pirenne, op. cit., I, blz. 368, was hij drapier in $1281 / 82$.

(32) Volgens de lijst van de borgen van 1281 waar hij als wever én als burger vermeld staat.

(33) Aldus vermeld in de lijst zelf.

(34) L. Gilliodts-Van Severen, op. cit., I, blz. 65 ( $\left.a^{\circ} 1299\right)$ en 107. Hij was schepen van Brugge in 1302/03: zie J. Colens, op. cit., blz. 2.

(35) L. Verriest, op. cit., blz. 493. - Werd opgenomen tamquam liber ... (zie noot 3 ).

(36) Wolhandelaar : zie G. Espinas-H. Pirenne, op. cit., III, blz. 708. (Hij verkocht 70 zakken wol te Ieper). - Drapier : de Brugse draperiekeure van 1294 (ibidem, I, blz. 463 en vlg.) werd te zijnen huize opgesteld en door hem overgeschreven (Stadsrek. 1294, $\left.f^{\circ} 22 v^{\circ}, f^{\circ} 26\right)$. - Lakenhandelaar : in 1298 werden zijn lakens aangeslagen : stadsrek. $1298, \mathrm{f}^{\circ} 17$.

(37) Dienaar van Jan van Kortrijk, volgens de lijst zelf.

(38) Pouwel senior was hostelier in 1281 (zie lijst van borgen).

Hij bezat 1000 à $2000 \mathrm{lb}$. in 1292 en $2000 \mathrm{lb}$. in 1297.

(39) L. Verriest, op. cit., blz. 497; J. Colens, op. cit., blz. XL;

L. Gilliodts-Van Severen, op. cit., I, blz. 290 ( $a^{\circ} 1305$ ).

(40) L. Verriest, op. cit., blz. 497.

(41) Volgens de lijst zelf. Zie ook L. Verriest, op. cit., blz. 499.

(42) Zie de lijst van borgen van 1281.

(43) Lamsin bezat $400 \mathrm{lb}$. in 1297.

(44) Volgens de lijst zelf. Zie ook J. Colens, op. cit., blz. 100.

(45) Zie de lijst van borgen in 1281.

(46) Jan de Mota was deken van de draperie in 1300 : zie rekening $1301, f^{\circ} 8$. In 1291 werd hij naar Ieper gestuurd om inlichtingen nopens de draperie aldaar: zie rekening 1291, f ${ }^{\circ} \mathbf{2 6}$. Hij was dienvolgens hoogst waarschijnlijk drapier.

(47) Zie de lijst van borgen in 1281.

(47 bis) Jan Quicken was lakensnijder in 1301 (zie L. Verriest, op. cit., blz. 497) en bezat 400 lb. in 1297.

(48) L. Gilliodts-Van Severen, op. cit., I, blz. 92.

(49) Ibidem, I, blz. 107.

(50) J. Colens, op. cit., blz. 82 (9 vaten wijn verbeurd).

(51) Een Lamsin van der Scare komt in de lijst van borgen voor onder de hosteliers en de blanders. Er is reden om aan te nemen dat het gaat om dezelfde persoon, die in werkelijkheid blander was.

(52) J. Colens, op. cit., blz. 135, 191.

(53) L. Gilliodts-Van Severen, op. cit., I, blz. 129.

(54) L. Verriest, op. cit., blz. 499.

(55) Ibidem, blz. 492. - Hij was gehuwd met een zuster van Jan Keminade, hostelier : zie C. Wyffels, Een ,opstand" te Brugge en de vlucht van Leliaarts naar Sint-Omaars tussen 17 augustus en 18 september 1297 (Hand. "Soc. Emul." te Brugge, dl. XC, 1953, blz. 63-72), blz. 72 . 
(56) Simon was drapier: G. Espinas-H. Pirenne, op. cit., I. blz. 368. In 1292 bezat hij 1000 à $2000 \mathrm{lb}$.

(57) L. Verriest, op. cit., blz. 495.

(58) L. Gilliodts-Van Severen, op. cit., I, blz. 108.

(59) Aldus vermeld in de lijst zelf. Zie ook rekening $1288, f^{\circ} 21$. f० 7 .

(60) $\mathrm{Hij}$ was deken van de volders in 1300 : zie rekening 1301 ,

(61) Bonin bezat $1000 \mathrm{lb}$. in 1297.

(62) L. Gilliodts-Van Severen, op. cit., I, blz. 290.

(63) Een Willem van Zomergem wordt als kleermaker vermeld in 1301 : L. Verriest, op. cit., blz. 497.

(64) Was deken van de strijpte draperie in 1295 : zie rekening $1295, f^{\circ} 4$.

(65) Lamsin was wijnkoopman of wijntapper: J. Colens, op. cit., blz. 83. (Hij verbeurde 2 laghelen wijn). 